\title{
Analisis Ekonomi Pemeliharaan Ayam Kamaras Jantan dengan Pemberian Tepung Ampas Tahu + Tepung Kulit Telur + Feed Supplement
}

\section{(The Economic Efficiency of Raising Male Kamaras Chicken with the Administration of Tofu Waste Meal + Egg Shell Meal + Feed Supplement)}

Murniati, Zulfan, M. Aman Yaman

Program Studi Peternakan, Fakultas Pertanian, Universitas Syiah kuala

\begin{abstract}
Abstrak : Tujuan penelitian ini adalah untuk melihat pengaruh penggunaan tepung ampas tahu + tepung kulit telur + feed supplement sebagai subtitusi sebagian ransum komersil terhadap efesiensi ekonomis pemeliharaan ayam kamaras jantan. Penelitian ini dilakukan di Laboratorium Lapangan Peternakan (LLP), Fakultas Pertanian, Universitas Syiah Kuala, tanggal 7 Januari-16 Maret 2016. Penelitian ini menggunakan 64 ekor DOC ayam kamaras. Perlakuan yang dicobakan adalah ransum komersil broiler 512 Bravo yang disubtitusi dengan tepung ampas tahu + tepung kulit telur + feed supplement sebanyak $0 \%\left(\mathrm{P}_{1}\right), 5 \%+1 \%+1 \%\left(\mathrm{P}_{2}\right)$, $10 \%+2 \%+1 \%\left(\mathrm{P}_{3}\right)$, dan $15 \%+3 \%+1 \%\left(\mathrm{P}_{4}\right)$. Parameter yang diamati adalah berat badan akhir, total konsumsi ransum, Income over Feed Cost (IOFC) dan total income. Hasil penelitian memperlihatkan bahwa meskipun secara statistik perbedaannya tidak nyata $(\mathrm{P}>0,05)$, substitusi ransum komersil broiler (512 Bravo) dengan tepung ampas tahu sampai $15 \%$ + tepung kulit telur $3 \%$ + feed supplement $1 \%$ meningkatkan berat badan akhir dan konsumsi ransum ayam kamaras, menurunkan biaya variabel ransum, dan total biaya, dan meningkatkan Income over Feed Cost (IOFC) dan total income pemeliharaan ayam kamaras. Substitusi ransum komersil broiler (512 Bravo) dengan tepung ampas tahu sampai $15 \%$ + tepung kulit telur $3 \%+$ feed supplement $1 \%$ layak dan menguntungkan dalam pemeliharaan ayam kamaras.
\end{abstract}

Kata Kunci : ampas tahu, kulit telur, ayam kamaras, income

\begin{abstract}
The purpose of this study was to determine effect of the use of tofu waste meal + egg shell meal + feed supplement as a partial substitution of broiler commercial ration to the economic efficiency of raising male kamaras chickens. The research was conducted at the Field Lab, Department of Animal Husbandry, Agricultural Faculty, Syiah Kuala University, January 7 to March 16, 2016. The study used 64 DOC of male kamaras chickens. The treatment tested was feeding male kamaras chickens with broiler commercial rations substituted by tofu waste meal + egg shell meal + feed supplement as much as $0 \%\left(\mathrm{P}_{1}\right), 5 \%+1 \%+1 \%\left(\mathrm{P}_{2}\right), 10 \%+2 \%+1 \%$ $\left(\mathrm{P}_{3}\right)$, and $15 \%+3 \%+1 \%\left(\mathrm{P}_{4}\right)$, respectively. Parameters measured were final body weight $(\mathrm{FBW})$, total feed consumption (TFC), and Income Over Feed Cost (IOFC) as well as total income. The results of study showed that although statistically no significant effects were detected ( $\mathrm{P}>0.05)$, using tofu waste meal up to $15 \%+$ egg shell meal $3 \%$ + feed supplement $1 \%$ as a partial substitution of broiler commercial rations tended to increase final body weight and total feed consumption of male kamaras chickens. Administration of these meal mixes was profitable, reduced cost and increased Income over Feed Cost (IOFC), and total income in raising of male kamaras chickens.
\end{abstract}

Keywords : tofu waste, eggshell, supplement, kamaras chicken, income

\section{PENDAHULUAN}

Ayam kamaras adalah hasil persilangan antara ayam ras jantan, ayam kampung betina, dan ayam arab betina (Yaman et al., 2011). Persilangan ketiga bangsa ayam ini dimaksudkan untuk memperbaiki kualitas dan produktivitas ayam kampung sebagai ayam petelur. Telur ayam arab memiliki kemiripan dengan telur ayam kampung, sedangkan produksi telurnya lebih tinggi daripada produksi telur ayam kampung (Natalia et al., 2005). Produktivitas ayam kampung memang masih rendah (Rasyaf, 2006).

Perkawinan induk betina ayam kampung dengan ayam ras jantan akan didapatkan ayam silangan yang memiliki produksi telur lebih tinggi. Ini dikarenakan ayam ras memiliki produksi telur yang tinggi (Abidin, 2003). Namun demikian, penampilan telur dari ayam 
hasil silangan ini akan menurun. Oleh karena itu, ayam jantan hasil silangan tersebut dikawinkan kembali dengan ayam arab betina, sehingga dihasilkan ayam silangan baru yang disebut ayam kamaras. Ayam kamaras ini kemudian dilakukan program out-breeding yang diikuti dengan seleksi sampai empat turunan untuk selanjutnya dijadikan ayam kamaras petelur.

Ayam kamaras diperkirakan memiliki kualitas daging yang lebih unggul daripada daging ayam arab. Hal ini dikarenakan adanya kombinasi genetik antara ketiga bangsa ayam tersebut. Pengembangan ayam kamaras pedaging secara komersial menemui beberapa masalah, antara lain biaya ransum. Jika ransum komersil broiler digunakan sepenuhnya maka dianggap kurang ekonomis, sehingga perlu disubstitusi dengan bahan pakan alternatif yang ketersediaannya berlimpah dan harganya lebih murah. Bahan pakan tersebut, antara lain, adalah ampas tahu dan kulit telur.

Ampas tahu merupakan hasil limbah padat yang telah diambil sarinya melalui proses pengolahan secara basah yang diperoleh dari proses pembuatan tahu dari kedelai. Ampas tahu mempunyai kadar gizi yang tinggi dan dapat dimanfaatkan sebagai pakan ternak (Pulungan dan Rangkuti, 1984; Raharjo, 2004; Tetty, 2006). Ampas tahu layak digunakan sebagai pakan ayam kampung (Tetty, 2006).

Kulit telur merupakan limbah yang terbuang karena tidak dikonsumsi oleh manusia. Kulit telur seringkali digunakan sebagai sumber kalsium (Butcher dan Miles, 1990) untuk campuran di dalam ransum komersil.

Penggunaan bahan-bahan pakan alternatif khususnya yang berasal dari hasil sampingan dan limbah dapat menyebabkan turunnya kualitas ransum. Hal ini disebabkan bahan pakan tersebut biasanya mengandung serat kasar yang cukup tinggi seperti halnya ampas tahu. Masalah ini dapat diatasi atau dikurangi, antara lain, dengan menambahkan suplemen. Feed supplement adalah bahan makanan berupa campuran preparat vitamin, mineral, dan antibiotika guna melengkapi ransum (Sudaryani dan Santoso, 2003). Berdasarkan hal tersebut perlu dilakukan penelitian untuk mengamati ekonomis pemeliharaan ayam kamaras pedaging yang diberi ransum komersil yang sebagian disubstitusi dengan tepung ampas tahu dan tepung kulit telur serta penambahan suplemen. Tujuan penelitian ini adalah untuk mengetahui ekonomis pemeliharaan ayam kamaras pedaging dengan pemberian ransum komersil yang sebagian disubstitusi dengan tepung ampas tahu + tepung kulit telur + feed supplement.

\section{MATERI DAN METODE}

\section{Tempat dan Waktu}

Penelitian ini dilakukan di Laboratorium Lapangan Peternakan (LLP), Program Studi Peternakan, Fakultas Pertanian, Universitas Syiah Kuala, Banda Aceh tanggal 7 Januari sampai dengan 16 Maret 2016.

\section{Materi, Bahan dan Alat Penelitian}

Penelitian ini menggunakan 64 ekor Day Old Chick (DOC) ayam kamaras. Bahan yang digunakan terdiri dari ransum komersil ( $\mathrm{R}_{511}$ Bravo dan $\mathrm{R}_{512}$ Bravo), ampas tahu, kulit telur ayam ras, feed supplement (top mix), desinfektan, koran bekas, kapur, litter, vitachick, vitastress, vaksin ND, dan vaksin gumboro. Peralatan yang digunakan meliputi tempat pakan, tempat minum, timbangan, bola lampu pemanas, bola lampu penerang. 


\section{Ransum Perlakuan}

Penelitian ini menggunakan ransum dasar berupa ransum komersil broiler R511 dan R512 (produksi PT. Charoen Phokphand, Medan). Ransum 512 disubstitusi dengan tepung ampas tahu + tepung kerabang telur + feed supplement. Susunan ransum perlakuan adalah sebagai berikut :

$\mathrm{P}_{1}=$ Ransum komersil R512 100\% (kontrol)

$\mathrm{P}_{2}=$ Ransum komersil R512 93\% + Tepung Ampas Tahu 5\% + Tepung Kulit Telur 1\% + Feed Supplement $1 \%$

$\mathrm{P}_{3}=$ Ransum komersil R512 87\% + Tepung Ampas Tahu 10\% + Tepung Kulit Telur $2 \%+$ Feed Supplement $1 \%$

$\mathrm{P}_{4}=$ Ransum komersil R512 81\% + Tepung Ampas Tahu 15\% + Tepung Kulit Telur 3\% + Feed Supplement 1\%

Tabel 1. Susunan dan Kandungan Zat Gizi Ransum Penelitian

Ransum Komersil Disubstitusi dengan Tepung Kulit Telur + Tepung Ampas Tahu + Feed Supplement

\begin{tabular}{lcccc}
\cline { 2 - 5 } Bahan Pakan & $\mathrm{P}_{1}$ & $\mathrm{P}_{2}$ & $\mathrm{P}_{3}$ & $\mathrm{P}_{4}$ \\
\hline R512 Bravo & 100 & 93 & 87 & 81 \\
Tepung Ampas Tahu $\left.^{* *}\right)$ & 0 & 5 & 10 & 15 \\
Tepung Kulit Telur $^{* * *}$ & 0 & 1 & 2 & 3 \\
Feed Supplement & 0 & 1 & 1 & 1 \\
Jumlah & 100 & 100 & 100 & 100
\end{tabular}

Kandungan Zat Gizi Berdasarkan Perhitungan

$\begin{array}{lcccc}\text { Protein }(\%) & 19,00-21,50 & 18,64-20,96 & 18,46-20,64 & 18,29-20,31 \\ \text { Serat Kasar }(\%)(\max ) & 5,00 & 6,08 & 7,20 & 8,33 \\ \text { Lemak Kasar }(\%)(\min ) & 5,00 & 5,05 & 5,15 & 5,25 \\ \text { Ca }(\%)(\min ) & 0,90 & 1,05 & 1,21 & 1,38 \\ \text { P }(\%)(\min ) & 0,60 & 0,57 & 0,54 & 0,51\end{array}$

*) Kandungan zat gizi berdasarkan label kemasan PT. Charoen Pokphand: protein kasar 19,0- 21,5\%, lemak kasar 5\%, serat kasar 5\%, Ca 0,9\%, dan P 0,6\%.

**) Kandungan zat gizi berdasarkan Direktorat Bina Produksi Peternakan dan Fakultas Peternakan IPB (1986): protein kasar sebesar 18,21\%, lemak 7,79\%, serat kasar 26,81\%, kalsium 0,47\% dan phospor $0,10 \%$

***) Kandungan zat gizi berdasarkan Lab. Ilmu Nutrisi Makanan Ternak IPB (2008): protein kasar 5,60\%, lemak 1,18\%, serat kasar 8,47\%, Ca 19,20\%, dan P 0,39\%

\section{Rancangan Penelitian}

Rancangan penelitian yang digunakan adalah Rancangan Acak Lengkap (completely randomized design), terdiri dari 4 perlakuan dan 4 ulangan. Setiap ulangan merupakan unit percobaan yang terdiri dari 4 ekor ayam sehingga total ayam 64 ekor. Perlakuan yang diberikan adalah penggunaan ransum komersil R511 dan R512 Bravo yang disubstitusi dengan tepung ampas tahu, tepung kulit telur ditambah feed supplement dengan taraf yang berbeda.

Model matematika penelitian yang digunakan menurut Steel dan Torrie (1993) adalah: $Y_{i j}=\mu+\tau_{i}+\varepsilon_{i j}$

Keterangan:

$Y_{i j} \quad$ : Nilai pengamatan

$\mu \quad$ : Nilai tengah umum

$\tau_{i} \quad$ : Pengaruh perlakuan ke- $i$ 


\section{$\varepsilon_{i j} \quad:$ Pengaruh galat perlakuan ke-i, ulangan ke-j}

\section{Pembuatan Tepung Ampas Tahu dan Kulit Telur}

Pembuatan tepung ampas tahu dilakukan dengan tahapan sebagai berikut: (1) ampas tahu dikumpulkan dari pabrik pembuatan tahu, (2) ditiriskan, (3) dijemur sampai kering di bawah sinar matahari, dan (4) digiling dengan menggunakan disc mill. Sedangkan pembuatan tepung kulit telur dilakukan dengan tahapan sebagai berikut: (1) kulit telur dikumpulkan dari pedagang martabak, (2) dicuci, (3) direbus, (4) ditiriskan, (5) dijemur sampai kering di bawah sinar matahari, dan (6) digiling dengan menggunakan disc mill.

\section{Pelaksanaan Penelitian}

Penelitian ini dilakukan dalam tiga tahap, yaitu:

a. Tahap Persiapan; Tahap persiapan meliputi persiapan kandang dan ransum. Persiapan kandang terdiri dari pembersihan kandang, sanitasi kandang (dalam kandang dan luar kandang), pencucian, penyemprotan desinfektan, persiapan tempat pakan dan tempat minum, dan pembuatan unit-unit percobaan. Masing-masing unit-unit percobaan diberikan kode perlakuan dan dilengkapi dengan lampu pijar sebagai pemanas. Persiapan ransum terdiri dari pembuatan tepung ampas tahu dan tepung kulit telur serta pencampuran bahan pakan.

b. Tahap Pemeliharaan; Tahap ini terdiri dari masa adaptasi dan masa pemberian perlakuan. Masa adaptasi dilakukan selama dua minggu dimana anak ayam dipelihara di dalam brooder dan diberi 100\% ransum komersil broiler 511 Bravo untuk semua perlakuan, konsumsi ransum tetap diperhitungkan. Setelah dua minggu, anak ayam ditempatkan secara acak ke dalam unit-unit percobaan dan diberi ransum sesuai perlakuan masing-masing sampai umur sepuluh minggu. Pemberian ransum dilakukan dua kali sehari, yaitu pada pukul 07.00 dan 17.00 WIB. Ransum diberikan ad libitum dan dihitung setiap seminggu sekali. Air minum juga diberikan ad libitum. Vaksinasi ND dilakukan pada umur 3 dan 21 hari melalui tetes mata, sedangkan vaksin gumboro pada umur 12 hari melalui tetes mulut. Pemberian vitachick dilakukan selama masa adaptasi, sedangkan vitastress diberikan saat-saat dilakukan penimbangan berat badan dan vaksinasi.

c. Tahap Pengambilan Data; Tahap pengambilan data dilakukan sejak awal hingga akhir penelitian. Data yang diambil selama penelitian adalah harga dan jumlah pemakaian input-input produksi seperti desinfektan, kapur, litter, DOC, vitamin, feed suplement, listrik, air, dan ransum. Data yang diambil pada akhir penelitian adalah berat badan akhir, total konsumsi ransum, dan harga jual ayam. Semua ayam dari tiap unit ditimbang untuk mengetahui berat badan akhirnya. Ransum sisa selama pemeliharaan sepuluh minggu ditimbang untuk mengetahui total konsumsi ransum yang dihabiskan. Harga jual ayam ditentukan berdasarkan harga jual yang berlaku di pasaran pada saat penelitian.

\section{Parameter Penelitian}

Parameter yang diukur dalam penelitian ini yaitu berat badan akhir, konsumsi ransum, penerimaan, biaya, Income over feed cost (IOFC), total income.

\section{Analisa Data}

Berat badan dan konsumsi ransum dianalisis dengan Analysis of Variance (ANOVA). Jika dari analisis tersebut didapatkan hasil yang berbeda nyata, maka dilanjutkan dengan uji Duncan (Steel dan Torrie, 1993). Data aspek ekonomis dianalisis dengan cara melihat kelayakan pemeliharaannya, yang dihitung melalui R/C dan B/C ratio (Sjahrial, 2008). 


\section{HASIL DAN PEMBAHASAN}

\section{Bobot Badan dan Total Konsumsi Ransum}

Dua parameter aspek produksi ayam kamaras yang sangat berkaitan dengan analisis aspek ekonomis adalah bobot badan badan akhir dan total konsumsi ransum selama pemeliharaan. Oleh karena itu, kedua parameter produksi tersebut dianalisis terlebih dahulu. Bobot badan akhir dan total konsumsi ransum ayam kamaras yang diberi ransum komersil yang disubstitusi dengan tepung ampas tahu + tepung kulit telur + suplemen selama pemeliharaan 8, 9, dan, 10 minggu diperlihatkan pada Tabel 2.

Hasil sidik ragam menunjukkan bahwa pemberian ransum komersil broiler 512 Bravo yang disubstitusi dengan tepung ampas tahu ditambah tepung kulit telur dan suplemen tidak berpengaruh nyata $(\mathrm{P}>0,05)$ terhadap rataan bobot badan akhir ayam kamaras yang ditimbang pada umur 8, 9, dan 10 minggu. Bobot badan akhir ayam kamaras dari semua perlakuan relatif sama. Meskipun demikian terlihat bahwa ayam-ayam yang diberi ransum yang mengandung tepung ampas tahu + tepung kulit telur + suplemen $\left(\mathrm{P}_{2}-\mathrm{P}_{4}\right)$ cenderung memiliki berat badan yang lebih tinggi dibandingkan dengan ayam yang mendapatkan ransum kontrol $\left(\mathrm{P}_{1}\right)$. Hal ini menunjukkan bahwa tepung ampas tahu dan tepung kulit telur ditambah suplemen dapat digunakan untuk mensubstitusi ransum komersil broiler 512 Bravo sampai 19\% tanpa menurunkan bobot badan badan akhir ayam kamaras, bahkan bobot badan cenderung meningkat. Bobot badan ayam kamaras terus meningkat sampai umur 10 minggu.

Tabel 2. Bobot Badan Akhir dan Total Konsumsi Ransum Ayam Kamaras yang Diberi Ransum Komersil dengan Substitusi Tepung Ampas Tahu + Tepung Kulit Telur + Feed Supplement

\begin{tabular}{|c|c|c|c|c|}
\hline \multirow[t]{2}{*}{ Parameter (Minggu) } & \multicolumn{4}{|c|}{ Perlakuan } \\
\hline & $\mathrm{P}_{1}$ & $\mathrm{P}_{2}$ & $\mathrm{P}_{3}$ & $\mathrm{P}_{4}$ \\
\hline \multicolumn{5}{|c|}{ Berat badan akhir (final body weight) (g/ekor) } \\
\hline Umur 8 minggu & $671,88 \pm 42,44$ & $694,63 \pm 34,25$ & $672,88 \pm 87,75$ & $689,31 \pm 65,35$ \\
\hline Umur 9 minggu & $727,13 \pm 42,29$ & $779,00 \pm 42,85$ & $750,25 \pm 110,06$ & $776,56 \pm 80,36$ \\
\hline Umur 10 minggu & $822,13 \pm 31,25$ & $848,13 \pm 46,16$ & $830,25 \pm 108,70$ & $857,50 \pm 86,72$ \\
\hline \multicolumn{5}{|c|}{ Total konsumsi ransum (total feed intake) (g/ekor) } \\
\hline $0-8$ minggu & $2066,27 \pm 61,65$ & $2069,21 \pm 28,26$ & $2037,19 \pm 105,79$ & $2078,77 \pm 87,47$ \\
\hline $0-9$ minggu & $2499,77 \pm 93,53$ & $2580,52 \pm 47,71$ & $2496,50 \pm 113,37$ & $2561,90 \pm 104,67$ \\
\hline $0-10$ minggu & $2981,25 \pm 122,44$ & $3072,40 \pm 46,42$ & $3089,57 \pm 140,47$ & $3076,15 \pm 102,26$ \\
\hline $\begin{array}{l}=\text { ransum komersil R512 } \\
=\text { ransum komersil R512 } \\
=\text { ransum komersil R512 } \\
=\text { ransum komersil R512 }\end{array}$ & pas ta & tepu & $\begin{array}{l}\text { suplemen } 1 \% \\
\text { suplemen } 1 \%\end{array}$ & \\
\hline
\end{tabular}

Meningkatnya berat badan ayam yang mendapatkan tepung ampas tahu + tepung kulit telur + suplemen diduga karena adanya tambahan unsur-unsur zat gizi yang berasal dari tepung ampas tahu + tepung kulit telur + suplemen yang dapat dimanfaatkan secara efisien oleh ayam kamaras untuk menaikkan berat badannya. Seperti yang dikatakan oleh Pulungan dan Rangkuti (1984), Raharjo (2004), Andy (2006), dan Tety (2006), limbah tahu masih mengandung protein yang cukup tinggi, namun rendah $\mathrm{Ca}$. Kekurangan mineral Ca dapat ditutupi dari tepung kulit telur yang mengandung $\mathrm{CaCO}_{3}$ yang tinggi (Butcher dan Miles, 1990). 
Kemungkinan lain kenaikan berat badan ayam-ayam kamaras yang mendapatkan ransum yang mengandung tepung ampas tahu + tepung kulit telur + suplemen adalah karena faktor kenaikan konsumsi ransumnya. Meskipun hasil sidik ragam, tidak ada perbedaan yang nyata dalam konsumsi ransum $(\mathrm{P}>0,05)$, ayam-ayam yang mendapatkan ransum yang mengandung tepung ampas tahu + tepung kulit telur + suplemen mengkonsumsi ransum lebih tinggi dibandingkan dengan ayam yang mendapatkan ransum kontrol $\left(\mathrm{P}_{1}\right)$. Hal ini memperlihatkan bahwa adanya tambahan tepung ampas tahu + tepung kulit telur + suplemen meningkatkan nafsu makan ayam. Seperti yang dikatakan oleh Anggorodi (1985), semakin banyak bahan pakan yang digunakan semakin palatabel ransum.

Hasil ini menunjukkan bahwa tepung ampas tahu + tepung kulit telur + suplemen dapat digunakan terus dalam pemeliharaan ayam kamaras hingga umur 10 minggu tanpa menunjukkan penolakan terhadap konsumsi ransum. Selain itu, respon terhadap berat badan masih lebih baik hingga pemeliharaan 10 minggu. Jelas terlihat bahwa tepung ampas tahu + tepung kulit telur + suplemen memberikan efek positif terhadap konsumsi ransum dan berat badan ayam kamaras. Namun demikian, apakah menguntungkan atau tidak maka pemeliharaan ayam kamaras perlu dianalisis secara ekonomis.

\section{Penerimaan}

Menurut Hanafie (2010), penerimaan total merupakan hasil kali produksi total dengan harganya. Berdasarkan hasil analisis penerimaan terlihat bahwa pemeliharaan ayam kamaras yang diberikan ransum komersil dengan substitusi tepung ampas tahu + tepung kulit telur + suplemen $\left(\mathrm{P}_{2}-\mathrm{P}_{4}\right)$ memiliki penerimaan lebih tinggi dibandingkan dengan pemeliharaan ayam kamaras yang hanya diberi ransum komersil $\left(\mathrm{P}_{1}\right)$, baik pada umur 8 maupun 9 atau 10 minggu. Hal ini dikarenakan ayam kamaras dari $\mathrm{P}_{2}-\mathrm{P}_{4}$ memiliki berat badan yang lebih tinggi daripada $\mathrm{P}_{1}$, sedangkan harga satuan penjualannya adalah sama untuk semua ayam kamaras.

Tabel 3. Penerimaan dari Pemeliharaan Ayam Kamaras pada Umur 8, 9, dan 10 minggu yang Diberi Ransum Komersil dengan Substitusi Tepung Ampas Tahu + Tepung Kulit Telur + Feed Supplement (Rp/ekor)

\begin{tabular}{ccccc}
\hline Pemeliharaan & \multicolumn{4}{c}{ Perlakuan } \\
\cline { 2 - 5 } & $\mathrm{P}_{1}$ & $\mathrm{P}_{2}$ & $\mathrm{P}_{3}$ & $\mathrm{P}_{4}$ \\
\hline 8 minggu & $26.875,20$ & $27.785,20$ & $26.915,20$ & $27.572,40$ \\
9 minggu & $29.085,20$ & $31.160,00$ & $30.010,00$ & $31.062,40$ \\
10 minggu & $32.885,20$ & $33.925,20$ & $33.210,00$ & $34.300,00$ \\
\hline
\end{tabular}

$\mathrm{P}_{1}=$ ransum komersil R512 $100 \%$ (kontrol)

$\mathrm{P}_{2}=$ ransum komersil R512 93\% + tepung ampas tahu 5\% + tepung kulit telur $1 \%+$ suplemen $1 \%$

$\mathrm{P}_{3}=$ ransum komersil R512 87\% + tepung ampas tahu $10 \%+$ tepung kulit telur $2 \%+$ suplemen $1 \%$

$\mathrm{P}_{4}=$ ransum komersil R512 81\% + tepung ampas tahu $15 \%+$ tepung kulit telur $3 \%+$ suplemen $1 \%$

Penerimaan lebih tinggi diperoleh pada pemeliharaan yang lebih lama (10 minggu) karena berat badan ayam pada umur tersebut juga lebih tinggi dibandingkan pada umur 8 atau 9 minggu. Namun demikian, penerimaan belum dapat digunakan untuk menggambarkan seberapa ekonomis pemeliharaan ayam kamaras. Oleh karena itu perlu pula dihitung biayabiaya yang diperlihatkan pada Tabel 4 . 


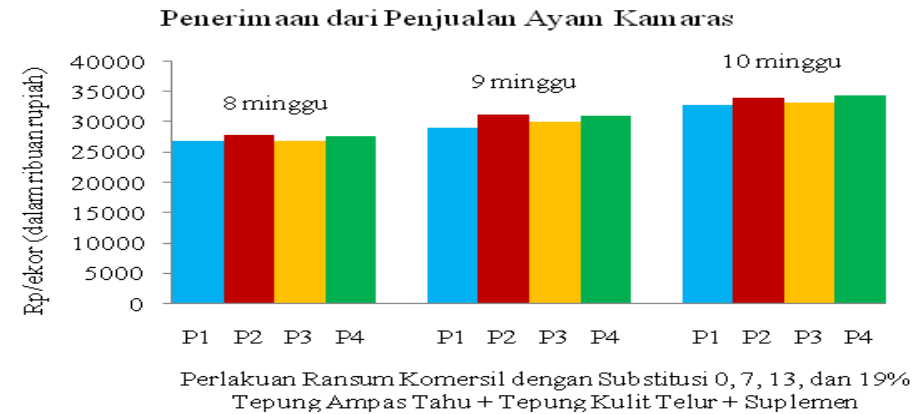

\section{Biaya Produksi}

Gambar 1. Total Penerimaan dari Hasil Pemeliharaan Ayam Kamaras dari Semua Perlakuan pada Umur 8, 9, dan 10 minggu

Hasil analisis memperlihatkan bahwa adanya penurunan total biaya pada pemeliharaan ayam-ayam kamaras yang diberi ransum komersil dengan substitusi tepung ampas tahu + tepung kulit telur + suplemen. Penurunan total biaya dikarenakan adanya penurunan biaya variabel, sedangkan biaya tetap (biaya kandang dan peralatan) tidak berubah. Penurunan biaya variabel dikarena adanya penurunan biaya ransum, sedangkan biaya variabel lainnya (DOC, listrik, tenaga kerja, litter, desinfektan, vitamin, dan vaksin) tidak berubah .

Tabel 4. Biaya Pemelihaaraan Ayam Kamaras pada Umur 8, 9, dan 10 minggu yang Diberi Ransum Komersil dengan Substitusi Tepung Ampas Tahu + Tepung Kulit Telur + Feed Supplement

\begin{tabular}{|c|c|c|c|c|}
\hline \multirow[t]{2}{*}{ Biaya $(\cos t)$} & \multicolumn{4}{|c|}{ Perlakuan } \\
\hline & $\mathrm{P}_{1}$ & $\mathrm{P}_{2}$ & $\mathrm{P}_{3}$ & $\mathrm{P}_{4}$ \\
\hline \multicolumn{5}{|c|}{ Biaya variabel (variable cost, $\mathrm{BV})$} \\
\hline \multicolumn{5}{|c|}{ BV Ransum $(\text { feed cost })^{1)}$} \\
\hline 8 minggu & 15.638 .33 & 15.047 .49 & 14.328 .46 & 14.116 .20 \\
\hline 9 minggu & 18.915 .59 & 18.752 .85 & 17.532 .26 & 17.358 .74 \\
\hline 10 minggu & 22.555 .58 & 22.313 .43 & 21.668 .99 & 20.810 .18 \\
\hline \multicolumn{5}{|c|}{ BV lain (other variable cost exclude feed cost) ${ }^{2)}$} \\
\hline 8 minggu & 7.966 .41 & 7.966 .41 & 7.966 .41 & 7.966 .41 \\
\hline 9 minggu & 8.327 .68 & 8.327 .68 & 8.327 .68 & 8.327 .68 \\
\hline 10 minggu & 8.712 .39 & 8.712 .39 & 8.712 .39 & 8.712 .39 \\
\hline \multicolumn{5}{|c|}{ Total $\mathrm{BV}^{3)}$ (total variable cost) } \\
\hline 8 minggu & $23.604,74$ & $23.013,90$ & $22.294,87$ & $22.082,61$ \\
\hline 9 minggu & $27.243,27$ & $27.080,53$ & $25.859,94$ & $25.686,42$ \\
\hline 10 minggu & $31.267,97$ & $31.025,82$ & $30.381,38$ & $29.522,57$ \\
\hline \multicolumn{5}{|c|}{ Biaya tetap $(\text { fixed cost })^{4)}$} \\
\hline 8 minggu & 740,00 & 740,00 & 740,00 & 740,00 \\
\hline 9 minggu & 740,00 & 740,00 & 740,00 & 740,00 \\
\hline 10 minggu & 740,00 & 740,00 & 740,00 & 740,00 \\
\hline \multicolumn{5}{|c|}{ Total Biaya $(\text { total } \operatorname{cost})^{4)}$} \\
\hline 8 minggu & $24.344,74$ & $23.753,90$ & $23.034,87$ & $22.822,61$ \\
\hline 9 minggu & $27.983,27$ & $27.820,53$ & $26.599,94$ & $26.426,42$ \\
\hline 10 minggu & $32.007,97$ & $31.765,82$ & $31.121,38$ & $30.262,57$ \\
\hline \multicolumn{5}{|c|}{$\begin{array}{l}\mathrm{P}_{1}=\text { ransum komersil R512 } 100 \% \text { (kontrol) } \\
\mathrm{P}_{2}=\text { ransum komersil R512 } \\
93 \% \text { + tepung am }\end{array}$} \\
\hline
\end{tabular}


$\mathrm{P}_{4}=$ ransum komersil R512 81\% + tepung ampas tahu $15 \%+$ tepung kulit telur $3 \%$ + suplemen $1 \%$

Ayam-ayam yang dipelihara dengan pemberian ransum komersil dengan substitusi tepung ampas tahu + tepung kulit telur + suplemen $\left(\mathrm{P}_{2}-\mathrm{P}_{4}\right)$ memiliki biaya ransum yang lebih rendah dibandingkan dengan ayam yang dipelihara dengan pemberian $100 \%$ ransum komersil $\left(\mathrm{P}_{1}\right)$. Semakin banyak tepung ampas tahu + tepung kulit telur digunakan semakin murah biaya ransum. Ini dikarenakan harga ransum substitusi lebih murah dibandingkan harga ransum komersil, sedangkan konsumsinya meskipun meningkat tetapi tidak terlalu tinggi.

Semakin lama pemeliharaan semakin meningkat biaya yang dikeluarkan. Peningkatan yang besar adalah pada biaya ransum sebab dengan semakin bertambahnya umur ayam maka semakin banyak pula konsumsi ransumnya, sedangkan biaya tetap dan biaya variabel lainnya tidak begitu banyak bertambah. Berdasarkan kenyataan ini maka perhitungan total income perlu dilakukan untuk mengetahui pada umur berapa paling menguntungkan pemeliharaan ayam kamaras.

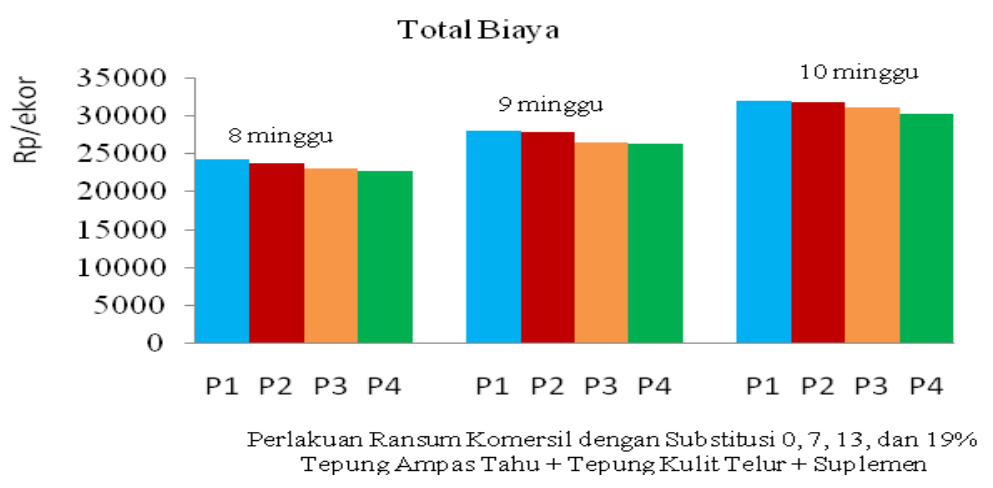

Gambar 2. Total Biaya dari Hasil Pemeliharaan Ayam Kamaras dari Semua Perlakuan pada Umur 8, 9, dan 10 minggu

\section{IOFC dan Total Income}

Hasil analisis income over feed cost (IOFC) memperlihatkan bahwa pemeliharaan ayam kamaras dengan pemberian ransum komersil yang disubstitusi dengan tepung ampas tahu + tepung kulit telur + suplemen $\left(\mathrm{P}_{2}-\mathrm{P}_{4}\right)$ menghasilkan IOFC yang lebih tinggi dibandingkan pemeliharaan ayam kamaras dengan pemberian $100 \%$ ransum komersil $\left(\mathrm{P}_{1}\right)$. Hal ini dikarenakan biaya ransum yang berkurang sebagai akibat dari penurunan harga ransum dari penggunaan tepung ampas tahu dan tepung kulit telur. Nilai IOFC dan total income pemeliharaan ayam kamaras diperlihatkan pada Tabel 5. 
Tabel 5. IOFC dan Total Income Pemelihaaraan Ayam Kamaras 8,9, dan 10 minggu yang Diberi Ransum Komersil dengan Substitusi Tepung Ampas Tahu + Tepung Kulit Telur + Feed Supplement

\begin{tabular}{|c|c|c|c|c|}
\hline \multirow[t]{2}{*}{ Keuntungan $^{1)}$} & \multicolumn{4}{|c|}{ Perlakuan } \\
\hline & $\mathrm{P}_{1}$ & $\mathrm{P}_{2}$ & $\mathrm{P}_{3}$ & $\mathrm{P}_{4}$ \\
\hline \multicolumn{5}{|l|}{ IOFC } \\
\hline 8 minggu & $11.236,87$ & $12.737,71$ & $12.586,74$ & $13.456,20$ \\
\hline 9 minggu & $10.169,61$ & $12.407,15$ & $12.477,74$ & $13.703,66$ \\
\hline 10 minggu & $11.973,88$ & $13.308,03$ & $13.201,51$ & $15.204,82$ \\
\hline \multicolumn{5}{|l|}{ Total Income } \\
\hline 8 minggu & $2.530,46$ & $4.031,30$ & $3.880,33$ & $4.749,79$ \\
\hline 9 minggu & $1.101,93$ & $3.339,47$ & $3.410,06$ & $4.635,98$ \\
\hline 10 minggu & $2.521,49$ & $3.855,64$ & $3.749,12$ & $5.752,43$ \\
\hline
\end{tabular}

Hasil analisis IOFC memperlihatkan bahwa pemeliharaan ayam kamaras masih menaikkan IOFC sampai pemeliharaan 10 minggu. Kenaikan IOFC paling besar adalah pada pemeliharaan ayam kamaras yang diberi ransum komersil dengan substitusi 19\% tepung ampas tahu + tepung kulit telur + suplemen $\left(\mathrm{P}_{4}\right)$. Sedangkan kenaikan paling kecil adalah pada pemeliharaan ayam kamaras yang diberi $100 \%$ ransum komersil $\left(\mathrm{P}_{1}\right)$.

Perhitungan IOFC belum dapat digunakan untuk menggambarkan tingkat keuntungan sebenarnya karena belum memperhitungkan biaya variabel lainnya. Oleh karena itu, analisis total income perlu dilakukan. Menurut Soekartawi (2002), keuntungan dapat dicapai jika jumlah penerimaan yang diperoleh dari hasil usaha lebih besar daripada jumlah pengeluarannya. Berdasarkan hasil analisis terlihat bahwa substitusi tepung + tepung kulit telur + suplemen menaikkan total income. Keuntungan tertinggi diperoleh pada pemeliharaan ayam kamaras sampai 10 minggu, dengan pemberian ransum komersil yang disubstitusi dengan 19\% tepung ampas tahu + tepung kulit telur + suplemen $\left(\mathrm{P}_{4}\right)$. Sedangkan keuntungan terkecil diperoleh pada pemeliharaan ayam kamaras yang diberi $100 \%$ ransum komersil $\left(\mathrm{P}_{1}\right)$ dengan lama pemeliharaan 9 minggu.

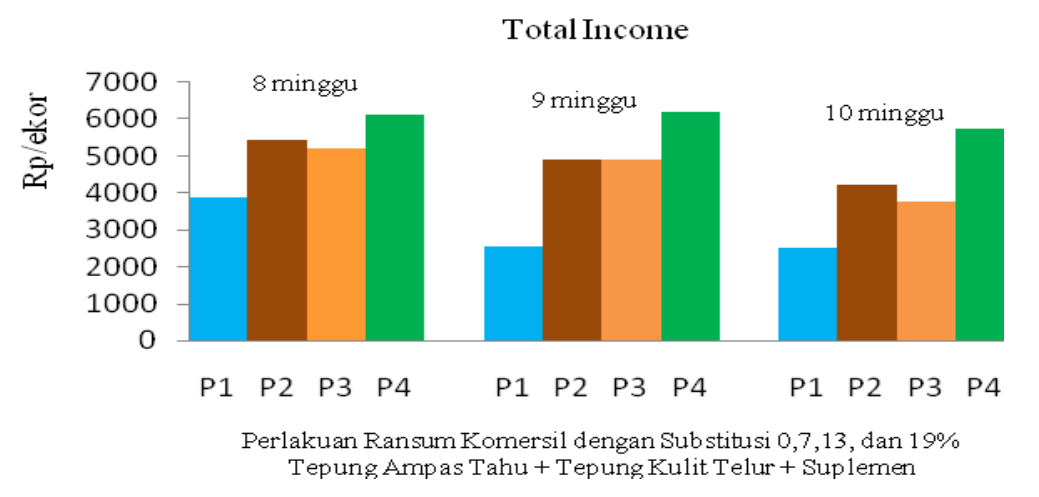

Gambar 3. Total Income dari Hasil Pemeliharaan Ayam Kamaras dari Semua Perlakuan pada Umur 8, 9, dan 10 minggu 


\section{Kelayakan Pemeliharaan}

Hasil analisis kelayakan usaha memperlihatkan semua ransum layak digunakan dan menguntungkan dalam pemeliharaan ayam kamaras pada semua umur $(8,9,10$ minggu) karena $\mathrm{R} / \mathrm{C}$ ratio $>1$ dan $\mathrm{B} / \mathrm{C}$ ratio $>0$. Seperti yang dikatakan oleh Sjahrial (2008), jika R/C ratio $>1$ dan $\mathrm{B} / \mathrm{C}$ ratio $>0$ berarti layak usaha dan menguntungkan. Nilai $\mathrm{R} / \mathrm{C}$ dan $\mathrm{B} / \mathrm{C}$ ratio pemeliharaan ayam kamaras yang diberi ransum komersil dengan substitusi tepung ampas tahu + tepung kulit telur + suplemen diperlihatkan pada Tabel 6.

Tabel 6. R/C dan B/C Ratio Pemelihaaraan Ayam Kamaras pada umur 8,9, dan 10 minggu yang Diberi Ransum Komersil dengan Substitusi Tepung Ampas Tahu + Tepung Kulit Telur + Feed Supplement

\begin{tabular}{ccccc}
\hline Komponen & $\mathrm{P}_{1}$ & $\mathrm{P}_{2}$ & $\mathrm{P}_{3}$ & $\mathrm{P}_{4}$ \\
\cline { 2 - 5 } & 1,104 & 1,170 & 1,168 & 1,208 \\
\hline R/C ratio & 1,120 & 1,128 & 1,175 \\
Umur 8 minggu & 1,039 & 1,121 & 1,120 & 1,190 \\
Umur 9 minggu & 1.079 & 0,170 & 0,168 & 0,208 \\
Umur 10 minggu & & 0,120 & 0,128 & 0,175 \\
B/C ratio & 0,104 & 0,121 & 0,120 & 0,190 \\
Umur 8 minggu & 0,039 & 0,079 &
\end{tabular}

$\mathrm{P}_{1}=$ ransum komersil R512 100\% (kontrol)

$\mathrm{P}_{2}=$ ransum komersil R512 93\% + tepung ampas tahu 5\% + tepung kulit telur $1 \%+$ suplemen $1 \%$

$\mathrm{P}_{3}=$ ransum komersil R512 $87 \%+$ tepung ampas tahu $10 \%+$ tepung kulit telur $2 \%+$ suplemen $1 \%$

$\mathrm{P}_{4}=$ ransum komersil R512 81\% + tepung ampas tahu $15 \%+$ tepung kulit telur $3 \%+$ suplemen $1 \%$

Berdasarkan hasil analisis diketahui bahwa pemeliharaan ayam kamaras yang paling layak dan paling menguntungkan adalah pemeliharaan ayam kamaras yang diberi ransum komersil yang disubstitusi dengan 15\% tepung ampas tahu $+3 \%$ tepung kulit telur $+1 \%$ suplemen $\left(\mathrm{P}_{4}\right)$ yang dijual pada umur 8 minggu karena perlakuan dan umur jual tersebut memiliki $\mathrm{R} / \mathrm{C}$ dan $\mathrm{B} / \mathrm{C}$ ratio tertinggi. Akan tetapi, jika pada umur tersebut ayam sulit dipasarkan maka penjualan pada umur 10 minggu pun masih memberikan keuntungan tertinggi bila ransum komersil yang diberikan disubstitusi dengan 15\% tepung ampas tahu + $3 \%$ tepung kulit telur $+1 \%$ suplemen $\left(\mathrm{P}_{4}\right)$ dibandingkan dengan penggunaan $100 \%$ ransum komersil.

\section{KESIMPULAN DAN SARAN}

\section{Kesimpulan}

Berdasarkan hasil penelitian yang telah dilakukan dapat disimpulkan bahwa substitusi ransum komersil broiler (512 Bravo, Produksi PT Charoen Pokhand) dengan tepung ampas tahu sampai $15 \%$ + tepung kulit telur $3 \%$ + feed supplement $1 \%$ meningkatkan berat badan akhir dan konsumsi ransum ayam kamaras, menurunkan biaya variabel ransum dan total biaya, dan meningkatkan Income Over Feed Cost (IOFC) serta total income pemeliharaan ayam kamaras. Substitusi ransum komersil broiler (512 Bravo) dengan tepung ampas tahu sampai $15 \%$ + tepung kulit telur 3\% + feed supplement $1 \%$ layak dan menguntungkan dalam pemeliharaan ayam kamaras. 


\section{Saran}

Bagi peternak yang mengusahakan ayam kamaras sebaiknya mensubstitusi ransum komersil broiler 512 Bravo dengan tepung ampas tahu sebanyak-banyaknya $15 \%$ ditambah tepung kulit telur 3\% dan feed supplement 1\%. Pemeliharaan ayam kamaras dengan pemberian ransum komersil yang disubstitutsi dengan tepung ampas tahu sebanyakbanyaknya $15 \%$ ditambah tepung kulit telur 3\% dan feed supplement $1 \%$ disarankan sampai umur 10 minggu karena paling tinggi keuntungannya. Perlu dilakukan penelitian lanjut perihal ayam kamaras terutama yang menyangkut dengan masalah ransumnya.

\section{DAFTAR PUSTAKA}

Abidin, Z, 2003. Meningkatkan Produktivitas Ayam Ras Petelur. Cet. ke-1. Agromedia Pustaka, Jakarta.

Andy. 2006. Komposisi Limbah Tahu. http://www. jurnal.lipi.go.id/utama.

Anggorodi, R. 1985. Kemajuan Mutakhir dalam Ilmu Makanan Ternak Unggas, PT. Gramedia, Jakarta.

Butcher, G. D. dan R. Miles. 1990. Concepts of Eggshell Quality. [Online]. (http://edis.ifas.ufl.edu/pdffiles/VM/VM01300.PDF 1990.

Hanafie, R. 2010. Pengantar Ekonomi Pertanian. CV. Andi Offset. Ed. ke-1, Yogyakarta.

Natalia, H., D. Nista, Sunarto, dan D.S. Yuni. 2005. Pengembangan Ayam Arab. Balai Pembibitan Ternak Unggul Sembawa (BPTU) Sapi Dwiguna dan Ayam Sembawa, Palembang.

Pulungan, H. dan M. Rangkuti. 1984. Ampas Tahu Untuk Makanan Ternak. Warta Penelitian dan Pengembangan Pertanian. Departemen Pertanian Bogor: 331-335.

Raharjo, L. 2004. Pemanfaatan tepung ampas tahu sebagai bahan pakan broiler periode finisher. Agritek 12:1

Rasyaf, M. 2006. Beternak Ayam Kampung. Penebar Swadaya, Jakarta.

Sjahrial, D. 2008. Kumpulan Pembahasan Soal-Soal Manajemen Keuangan. Ed. ke-1. Penerbit Mitra Wacana Media, Jakarta.

Soekarwati, A., Soehardjo, J. Dillon, dan J. B. Hardaker. 1986. Ilmu Usahatani dan Penelitian untuk Pengembangan Petani Kecil. Universitas Indonesia, Jakarta.

Steel, R. G. D. dan J. H. Torrie, 1993. Prinsip dan Prosedur Statistika. Terjemahan oleh B. Sumantri. Cet. ke-2. PT. Gramedia, Jakarta

Sudaryani, T. dan H. Santosa, 2003. Pembibitan Ayam Ras. Cet. ke-7. Penebar Swadaya, Jakarta.

Tetty. 2006. Pemanfaatan Kulit Pisang dan Ampas Tahu Terhadap Kinerja Pertumbuhan Ayam Buras. http://balitnak.litbang.deptan.go.id $/ \mathrm{mod}$. php?mod=publisher\&op= viewarti cle\&artid $=88$.

Yaman, M.A., Yurliasni, dan Zulfan. 2011. Peningkatan Potensi Genetik Ayam Lokal Melalui Kombinasi Metode Seleksi dengan Analisa Protein, RNA, dan M-RNA, Aplikasi Kawin Silang (croosbreeding) Serta Penyesuai Nutrisi Untuk Mendapatkan Kandidat Pejantan Ayam Petelur Unggul. Laporan Penelitian Insentif Riset Terapan Kemenristek. 